\title{
Reviews
}

\section{A Review of Weed Control Practices in Container Nurseries}

\author{
L.T. Case $^{1}$, H.M. Mathers ${ }^{1}$, and A.F. Senesac ${ }^{2}$
}

ADDITIONAL INDEX WORDS. container production, herbicides, weed controls

Summary. Container production has increased rapidly in many parts of the U.S. over the past 15 years. Container production has been the fastest growing sector in the nursery industry and the growth is expected to continue. Weed growth in container-grown nursery stock is a particularly serious problem, because the nutrients, air, and water available are limited to the volume of the container. The extent of damage caused by weeds is often underestimated and effective control is essential. Various researchers have found that as little as one weed in a small ( 1 gal) pot affects the growth of a crop. However, even if weeds did not reduce growth, a container plant with weeds is a less marketable product than a weedfree product. Managing weeds in a container nursery involves eliminating weeds and preventing their spread in the nursery, and this usually requires chemical controls. However, chemical controls should never be the only management tools implemented. Maximizing cultural and mechanical controls through proper sanitation and hand weeding are two important means to prevent the spread and regeneration of troublesome weeds. Cultural controls include mulching, irrigation methods (subirrigation), and mix type. Nursery growers estimate that they spend $\$ 500$ to $\$ 4000$ /acre of containers for manual removal of weeds, depending on weed species being removed. Economic losses due to weed infestations have been estimated at approximately $\$ 7000 /$ acre. Reduction of this expense with improved weed control methodologies and understanding weed control would have a significant impact on the industry. Problems associated with herbicide use in container production include proper calibration, herbicide runoff concerns from plastic or gravel (especially when chemicals fall between containers) and the need for multiple applications. As with other crops, off-site movement of pesticides through herbicide leaching, runoff, spray drift, and non-uniformity of application are concerns facing nursery growers. This article reviews some current weed control methods, problems associated with these methods, and possible strategies that could be useful for container nursery growers.

$\mathrm{N}$ urseries spend large amounts on manual removal of weeds, sometimes as much as $\$ 4000$ / acre (Mathers, 2003). Based on an hourly wage of $\$ 14.75$, it costs $\$ 1367$ to hand weed $10003-\mathrm{L}$ pots over a 4-month period (Darden and Neal, 1999). This seems like a lot of money; however, the markets for nursery crops demand weed-free container-grown plants (Simpson et al., 2002). It is evident that although weed control is essential for growers, an abundance of money and time is required to control weeds in containers.

In a survey of 32 Alabama nurseries in 1987 by Gilliam et al. (1990), yellow nutsedge (Cyperus esculentus), prostrate spurge (Euphorbia maculata), woodsorrel (Oxalis corniculata or O. stricta), and eclipta (Eclipta alba) were the most difficult weeds to control. Table 1 contains a list of common container weeds that are difficult to control in a variety of U.S. nursery states. Weed problems are not limited to higher plant forms. Silver thread mosses (Bryum argenteum) and liverwort (Marchantia spp.) also can be problematic in container production (Mathers, 2003) and have spread throughout the U.S. nursery industry rather quickly (Fausey, 2003). Both pests are highly invasive and difficult to control in containerized ornamentals (Fausey, 2003). Ornamental liners are produced in one region of the country and then shipped to another for finishing, and shipped again for retail. The containers acquire and disseminate weeds at each point in time (Fausey 2003).

How many weeds does it take before growth is affected? Various researchers have found that as little as one weed in a small $(1 \mathrm{gal})$ pot affects the growth of a crop (Berchielli-Robertson et al., 1990; Fretz, 1972; Walker and Williams, 1989), but this is highly dependent on weed and crop species present. For example, one large redroot pigweed (Amaranthus retroflexus) or large crabgrass (Digitaria sanguinalis) plant per pot reduces the growth of 'Convexa' japanese holly (Ilexcrenata) by $47 \%$ and $60 \%$, respectively (Fretz, 1972). As few as one eclipta plant can reduce the shoot dry weight of 'Fashion' azalea (Rhododendron $\mathrm{x}$ 'Fashion') (Berchielli-Robertson etal., 1990). Walker and Williams (1989) reported that 'Gold Drop' potentilla (Potentilla fruiticosa) is very sensitive
${ }^{1}$ Department of Horticulture and Crop Science, Ohio State University, Columbus, OH 43210-1096.

${ }^{2}$ Cornell Cooperative Extension, Long Island Horticultural Research and Extension Center, Riverhead, NY 11901.

Salaries and research support provided by state and federal funds appropriated to the Ohio Agricultural Research and Development Center, The Ohio State University. Manuscript number HCS 03-37. We acknowledge the technical assistance provided by James Beaver in the preparation of this manuscript.

\begin{tabular}{llll}
\hline $\begin{array}{l}\text { Units } \\
\text { To convert U.S. to SI, } \\
\text { multiply by }\end{array}$ & U.S. unit & SI unit & $\begin{array}{l}\text { To convert SI to U.S., } \\
\text { multiply by }\end{array}$ \\
\hline 0.4047 & acre(s) & ha & 2.4711 \\
3.7854 & gal & $\mathrm{L}$ & 0.2642 \\
2.5400 & inch(es) & $\mathrm{cm}$ & 0.3937 \\
1 & $\mathrm{ppm}$ & $\mathrm{mg} \cdot \mathrm{L}^{-1}$ & 1
\end{tabular}


Table 1. Common nursery weeds listed by family and life cycle (Altland 2003; Gilliam et al. 1990; Norcini and Stamps, 1994).

\begin{tabular}{|c|c|c|c|}
\hline Common name & Scientific name & Division or family & Life cycle \\
\hline Redroot pigweed & Amaranthus retroflexus & Amaranthaceae & Summer annual \\
\hline Hairy bittercress & Cardamine hirsuta & Brassicaceae & Winter annual \\
\hline Pennsylvania bittercress & Cardamine pensylvanica & Brassicaceae & Winter annual \\
\hline Prostrate spurge & $\begin{array}{l}\text { Chamaescyce maculata } \\
\text { or Eurphorbia maculata }\end{array}$ & Eurphorbiaceae & Summer annual \\
\hline Hellow nutsedge & Cyperus esculentus & Cyperaceae & Perennial \\
\hline Large crabgrass & Digitaria sanguinalis & Poaceae & Summer annual \\
\hline Eclipta & Eclipta prostrata & Asteraceae & Summer annual \\
\hline Northern willowherb & Epilobium ciliatum & Onagraceae & Summer annual \\
\hline Mulberry weed & Fatoua villosa & Moraceae & Summer annual \\
\hline Creeping red woodsorrel & Oxalis corniculata & Oxalidaceae & Perennial (spreads by stolons) \\
\hline Common yellow woodsorrel & Oxalis stricta & Oxalidaceae & Perennial (spreads by rhizomes) \\
\hline Longstalked phyllanthus & Phyllanthus tenellus & Euphorbiaceae & Perennial \\
\hline Annual bluegrass & Poa annua & Poaceae & Winter annual \\
\hline Common purslane & Portulaca oleracea & Portulacaceae & Summer annual \\
\hline Birdseye pearlwort & Sagina procumbens & Caryophyllaceae & Perennial \\
\hline Common groundsel & Senecio vulgaris & Asteraceae & Winter annual \\
\hline Annual sowthistle & Sonchus oleraceus & Asteraceae & Summer annual \\
\hline Common chickweed & Stellaria media & Caryophyllaceae & Summer or winter annual \\
\hline Dandelion & Taraxacum officinale & Asteraceae & Perennial \\
\hline
\end{tabular}

to weed interference and the grassy weed economic threshold for these plants is less than one per container. Norcini and Stamps (1994) indicate one large crabgrass plant in a 1 -gal container can reduce the growth of a 'Convexa' japanese holly liner by $60 \%$. However, even if weeds do not reduce growth, a container plant with weeds is a less marketable product than a weed-free product (Norcini and Stamps, 1994).

\section{Scouting and infestation sources}

Weed identification and scouting are essential for proper weed control. The species that are most prevalent should get the most attention, however, the less prevalent should not be overlooked as these can become problematic in the future. After the weeds have been identified, they should be grouped by lifespan. Perennials tend to be more problematic in terms of control. Weeds that escaped current weed management practices and any weeds on state or federal noxious weed lists deserve high priority. Special consideration should also be given to any new species of weeds. Scouting for weeds is not like scouting for insects (Neal, 1999). Determining exact population levels or numbers of species is not the intent. The purpose of weed scouting is to determine which weeds threaten your business (Neal, 1999). Control, not abolishment, should be the key to keep in mind.

Container nursery weed scouting should be scheduled at minimum of three or four times a year. First, a spring evaluation should be conducted to determine which weeds have escaped the fall preemergence program and which winter annuals are germinating. Then, a summer evaluation( $(s)$ should be conducted to identify summer annuals that are escaping the spring preemergence program and winter annuals that are persisting. Third, in the fall before the first frost, summer annuals and perennials that have escaped control and winter annual seedlings should be identified (Neal, 1999).

Managing weeds in a container nursery involves eliminating weeds and preventing their spread (Fausey, 2003). This usually requires chemical controls, but these should never be the only management tools implemented. Maximizing cultural and mechanical controls through proper sanitation and hand weeding are two important means to prevent the spread and regeneration of troublesome weeds (Fausey, 2003). It is important to eliminate problematic weeds before they have time to spread.

Proper sanitation ensures that wind dispersal of weed seeds from adjacent areas is minimized, since this can be a major source of imported weed seeds (Elmore and Wilen, 2000). Adjacent areas in container nurseries include fence lines, roads, irrigation ditches, the container yard (between and near pots), and around shade structures and other nursery buildings. Some common container weed species from Table 1 that are easily wind-dispersed include: annual sowthistle (Sonchus oleraceus), common groundsel ( $\mathrm{Se}$ necio vulgaris), horseweed (Conyza canadensis), and northern willowherb (Epilobium ciliatum). Non-crop area or adjacent area weeds can also harbor many types of insects, which in turn can transmit disease or directly attack the crop (Cranston, 1994). Weeds can 
also serve as secondary hosts for crop pathogens (Hobbs et al., 1996). Other sources of weed seed introduction are irrigation water, vehicles, equipment, birds and movement of soil (Elmore and Wilen, 2000).

Weed seed contamination of container mixes can be another major source of problems (Elmore and Wilen, 2000). Conducting a germination test to see if weed seeds are present in the media before planting is one way to control potential weed problems. Limiting exposure of mix to potential weed seed blow-in by covering mix piles (Elmore and Wilen, 2000) and isolation of containers purchased from other nurseries until they are determined to be weed-free are important steps. If prevention of weed seed infestation is not possible, then weed control can be implemented through several methods.

\section{Cultural control of weeds}

Different approaches have been used to control weeds to economical and aesthetic levels, any many have been quite successful. Cultural controls include mulching, subirrigation(Wilen et al., 1999), using large-porous media (Altland, 2004) in the containers, and as previously mentioned, keeping the media covered to prevent seed contamination.

One of the first ways to suppress weed growth was to use mulch in the surrounding area of the plant (Robinson, 1988). Mulch is any material, other than soil, specifically established at the soil-air interface to manage soil and water and create favorable environments for plant growth (Lal, 2002). Mulches are effective suppressors of water evaporation (Scholl and Schwemmer, 1982). Organic mulches suppress weeds by inhibition of germination and suppression of weed growth (Mathers, 2002a). Mulches have not been used extensively as weed suppressants in container production. However, there are a number of organic mulches that have been proposed and investigated for container weed control. These range from the bark of different trees, to Wulpack (Horti-feeds, Lincoln, U.K.), which is pelletized wool left over from sheep trimmings, and PennMulch (Lebanon Seaboard Corp., Lebanon, Pa.), a pelletized version of shredded newspaper. Both Wulpack and PennMulch double their volume when rainfall/irrigation is applied (Abbey et al, 2001; Mathers and Ozkan, 2001).

Rice hulls have been used as mulch in containers and have been known to be efficacious on different weeds (Ahn and Chung, 2000). Pine bark nuggets, shredded hardwood mulch, and cypress mulch when applied in the landscape or in containers significantly reduced weed counts (Billeaud and Zajicek, 1989). Landscape mulches also have been shown to not provide the weed control desired by commercial and non-commercial landscapers. Skroch et al. (1992) found only 50\% reduction in weeds from bark mulches at 3.5 inches thick, which was not acceptable. One disadvantage of organic mulches is that they can reduce the amount of readily available nitrogen (Billeaud and Zajicek, 1989). Mulches with high carbon: nitrogen $(\mathrm{C}: \mathrm{N})$ ratios will require additional nitrogen source due to the high uptake by soil microbes of released nitrogen (D. Eckert, personal communication). Over time, the C:N ratio will stabilize around $10: 1$, and then there will be an increased amount of nitrogen from organic matter.

Other cultural methods include: woven textiles such as collars or the Geodisc (Texel USA, Hendersonville, N.C.), a needle punched, nonwoven polypropylene fabric treated on one side with copper hydroxide (Spinout; Griffin LLC, Valdosta, Calif.) have been used to reduce weed competition (Mathers, 2003) in l-gal pots. In a study with containers containing willow oak (Quercus phellos) seedlings Appleton and French (2000) found the Geodisc provided complete weed control. The Geodisc is the most commonly used "non-chemical" weed control alternative to hand-weeding in container nurseries, although copper hydroxide is a chemical. Disadvantages of the Geodisc include size of the opening in the disc for the plant, and wind blowing the disc from the pot. Plastic lids called Enviro LIDs (Enviro LID, Langley, B.C.) that fit over the container with holes for the plants have been used in container nurseries (Mathers, 2003). Polyethylene sleeves have been used by Mori Nurseries in Niagara-on-the-Lake, Ont. (Mathers, 2003).

\section{Chemical control of weeds}

Modern herbicide technology was triggered with the introduction of 2,4 dichlorophenoxyacetic acid $(2,4-\mathrm{D})$ in 1941 (Ross and Lembi, 1999). By 1996, there were over 140 herbicides available for use (Weed Technology, 1996). The number of herbicides available to the ornamental industry is considerably less. The overall number of ornamental species produced limits the number of plant species that can be tested for herbicide tolerance and thus the number that can be listed on herbicide labels (Mervosh and Ahrens, 1998). The early stages of container production are especially problematic for growers as many products registered for use on established ornamentals or major commodity crops such as cotton (Gossypium hirsutum), corn (Zea mays), and soybeans (Glycine max) are injurious to newly established ornamentals (Fausey, 2003). Nursery growers are often left with limited weed-management strategies for specific groups of ornamentals (Fausey, 2003).

Herbicides are effective when used in the proper manner. Bittercress (Cardamine spp.) is one of the most common weeds of nursery production (Ryan, 1977), but with an effective weed management program, it can be controlled in the containers (Cross and Skroch, 1992) and in the surrounding areas of the containers with a number of different herbicides (Briggs et al., 2001). Herbicides for container-grown plants should be highly effective on weeds, yet have low phytotoxicity on the container-grown plants. Herbicides can and should be applied shortly after potting, although certain precautions should be taken. Due to the large macropores that are present right after potting, herbicides can more easily reach the roots (Altland, 2002). Dinitroaniline herbicides that can cause root damage should be used with caution. Derr and Salihu (1996) found that abelia (Abelia x grandiflora) root growth can be damaged following oryzalin applications. Oryzalin is the most soluble and leachable of the dinitroaniline herbicides.

Identifying weeds is important in nursery container weed control for choosing the correct herbicide to apply. Most herbicides are selective, meaning that the herbicide only kills or prevents seed establishment of certain species. Herbicides can be used preemergence or postemergence, although some herbicides can be used for both. Preemergence herbicides are classified as controlling primarily grasses, broadleaf weeds, or sedges (Cyperus spp.) 
(Altland et al., 2003). Even though herbicides may be selective for broadleaf weeds, the crop, which could also be a broadleaf, might be unaffected. This is another example of selectivity. Herbicides can also be nonselective (e.g., glyphosate), which means that they kill most of the plant species present, regardless of the status as a crop or weed. An example of related weeds that exhibit differential response to herbicides is illustrated in the mustard family (Brassicaceae). Potential weeds in this family include hairy bittercress and pennsylvania bittercress (Table 1). Most preemergence herbicides are effective on the mustards with the exception of trifluralin. Glyphosate and 2,4-D applied as a postemergence directed spray control these weeds. Another example is the pink family (Caryophyllaceae). Members of the pink family that may be container weed problems include chickweed (Stellaria spp.), and birdseye pearlwort (Sagina procumbens) (Table 1). Members of the pink family are controlled by most preemergence herbicides, including simazine, diuron, dichlobenil, oryzalin, and pronamide. Many pink family members, however, are tolerant to oxadiazon. Glyphosate and paraquat are effective postemergence controls, but 2,4-D provides variable control depending on the pink family species.

Weed management in herbaceous perennial production is even more problematic than in woody ornamental nurseries. The large number of herbaceous perennial species and varieties that are usually grown at even small nurseries complicates the search for herbicides that are generally well tolerated and effective. In the recent past, a number of herbaceous perennial species have been added to the labels of a few preemergent herbicides such as pendimethalin, isoxaben, and isoxaben plus oryzalin. These additions have made it possible for limited weed management with preemergent materials in herbaceous perennial nurseries and landscapes (Senesac, 2002a). However, due to the sensitivity of herbaceous perennial foliage and growth habits, it has not been possible to find preemergent herbicides that can be sprayed over the top of a wide variety of herbaceous perennials (Senesac, 2004). With the obvious exception of ornamental grasses, herbaceous perennials generally tolerate the postemergent graminicides fairly well. As a result, graminicides are now labeled for use on a substantial number of species. These materials can be useful tools to manage summer annual grasses such as crabgrass (Senesac, 2002b).

\section{How herbicides work}

Most herbicides have a specific target site in the plant that they bind to and inhibit some physiological function (Hall et al., 1999). Mode of action can be defined as the primary mechanism of herbicide interference with plant function or metabolism that leads to plant death (Loux et al., 2002). Herbicides with the same mode-of-action tend to have the same translocation (movement) pattern, produce similar injury symptoms (Ross and Childs, 1996), exhibit similar toxicological profiles, and frequently require the same application method (Hall et al., 1999). Some commonly used ornamental herbicides can be divided into 12 different groups based on mode-of-action, as indicated in Table 2. Selectivity on crops and weeds, behavior in the soil, and use patterns are less predictable, but often similar for herbicides with the same mode-of-action (Ross and Childs, 1996).

One or more vital processes in the plant must be disrupted in order for herbicides to kill a plant. Many herbicide target sites are enzymes; however, there are exceptions. Some vital metabolic plant processes that herbicides act on include: photosynthesis (capture of light and carbohydrate synthesis), amino acid and protein synthesis, fat (lipid) synthesis, pigment synthesis, nucleic acid synthesis, and maintenance of membrane integrity (Ross and Childs, 1996). Other ways herbicides act to kill plants include: disruption of mitosis (cell division) in plant meristems (shoots or roots), disruption of meiosis (division resulting in gamete and seed formation), interference of uptake of ions and molecules, translocation of ions and molecules, and transpiration.

Preemergent herbicides do not prevent germination, but are absorbed by the weed through growing tissue (hypocotyl, shoot tip, root tip) and inhibit growth of the seedling. Most preemergent herbicides used in container production include a dinitroaniline herbicide. Root inhibition and lodging frequently occur with dinitroaniline herbicides (Ashton and Crafts, 1981). The mode of action of dinitroaniline herbicides is through inhibition of growth in the meristematic regions in the young plant by preventing polymerization of tubulin in the cell division process (Morejohn et al., 1987). Despite the knowledge that dinitroanilines are root inhibitors and three to five applications of preemergent herbicides may be required to keep the "chemical barrier" on the container surface, there have been few studies that have investigated the affects of these herbicides on root development of the crop in container production.

\section{Herbicide resistance}

The repeated use of one herbicide or herbicides with the same mode of action may allow a few plants in a population to develop herbicide resistance. Herbicide resistance according to the Weed Science Society of America is "the inherited ability of a plant to survive and reproduce following exposure to a dose of herbicide normally lethal to the wild type." In a plant, resistance may be naturally occurring or induced by such techniques as genetic engineering or selection of variants produced by tissue culture or mutagenesis (Heap et al., 2004). There are different possible mechanisms by which a population of weeds can become resistant. One idea is that herbicide-resistant plants are originally present in a population in very small numbers. The repeated use of one herbicide allows these few plants to survive and reproduce, while those that are not resistant die before they can reproduce (Mallory-Smith et al., 1999). There is then a higher population of the resistant biotype present. Another way that herbicide-resistance may develop is a genetic mutation which develops after the herbicide has been applied, and this mutation then provides resistance to the herbicide (Hager et al., 1998). The plants that have resistance can then resistance genes to its offspring.

The development of herbicideresistant weed biotypes is a dilemma that is facing producers of various agricultural and horticultural crops all over the world. A biotype is defined as a population of weeds within a given species that possess certain traits not common to the entire population of the species. Some biotypes of weeds can possess multiple resistance, which is resistance to herbicides from families with different modes of action (Mal- 
lory-Smith et al., 1999). Although the problem of herbicide-resistant weeds is not widespread in nursery culture, nursery managers should become knowledgeable about how resistance develops so that the potential threat and occurrence of resistant weeds can be minimized (Hager et al., 1998).

It was once thought that using herbicides from different chemical families would prevent resistance. However, this is no longer the case (Mallory-Smith et al., 1999). For example, two chemically different groups of herbicides, the sulfonylureas and imidazolinones, have the same site of action [acetolactate synthase (ALS) inhibitors]. Using one of these two herbicide families repeatedly could lead to the development of biotypes resistant to both herbicide families. This type of resistance development would be called cross-resistance. Table 2 indicates chemical families that have been shown to result in cross-resistance among weed species by giving them the same herbicide resistance activity code (HRAC)(Prather et al., 2000). The imidazolinones are primarily used as preemergents and the sulfonylureas are postemergents, although the sulfonylureas can have some residual activity even when applied postemergence. Many nursery growers think applying herbicides at different times (i.e., pre- or postemergence) means that they are applying herbicides with different modes-of-action; however, the example listed above indicates that this is not true.

There are numerous reports of weed resistance to various herbicides. wimmera ryegrass (Lolium rigidum), a common weed in Australia, is resistant to most of the selective herbicides used in Australia (Powles and Matthews, 1992). Now, many biotypes of wimmera ryegrass are resistant to glyphosate (Pratley et al., 1999), a common non-selective herbicide used in container yards. There are not many reports of weeds being resistant to glyphosate, although biotypes of field bindweed (Convovlus arvensis) have shown to be variably controlled by glyphosate (DeGenanaro and Weller, 1984). Horseweed has recently been shown to be the first annual broadleaf weed resistant to glyphosate (VanGessel, 2001). At present time, there are seven weed species with confirmed resistance to glyphosate (Heap et al., 2004). With the continued high use of glyphosate, it can be speculated that there will be more species that will be found to be resistant to glyphosate.

\section{Common nursery herbicides}

Granular preemergent herbicides are the most common type of formulations used in container production (Gilliam et al., 1992). In Alabama, three common herbicides in container nurseries are oxadiazon and two combination herbicides, pendimethalin plus oxyfluorfen and oryzalin plus oxyfluorfen (Gilliam et al., 1990). Newer granular herbicide premixes including oxadiazon plus prodiamine, and oxyfluorfen plus oxadiazon are becoming more popular for their broad spectrum of weed control. Flumioxazin, a relatively new chemical in the nursery industry is now registered for use as a preemergence and early postemergence herbicide in much of the U.S. Most herbicides used in container production are listed in Table 2 .

Generally, only preemergent herbicides are used in container production, however, glyphosate is commonly used as a postemergent in the container yard between crops and around shade structures. Glyphosate can also be used, with great care, around the plant in the container when some particularly difficult weeds become established, like woodsorrel, bittercress, or liverworts. Glyphosate should be applied only at low pressure and low volume with a shield and with extreme care to avoid contact with the stock plant. Some nurseries that have adopted a zerotolerance for weeds such as liverworts use glyphosate following the precautions indicated above. These nurseries do anticipate stock losses using glyphosate; however, because of their zero-tolerance policy with weeds, they already consider the containers with liverworts not marketable, so death of this stock is a moot point. Once the woodsorrel, bittercress or liverworts are dead, nursery personnel will apply preemergence herbicides.

The multitude of plant species in a typical nursery makes it hard to find and even develop a postemergent herbicide that would not be phytotoxic to at least one of the species. Thus, postemergence control of weeds is not a viable option for many nurseries. There are numerous reports of species being tolerant to postermergence herbicides while still effective on target weeds. Bittercress can be controlled postemergence with isoxaben and imazaquin (Altland et al., 2000a, 2000b), however, imazaquin was found to be phytotoxic to 'Midnight Flare' azalea (Altland et al., 2000a). Simpson et al. (2002) reported that oxalis could be controlled postemergence with diuron in container-grown 'Big Blue' lilyturf (Liriope muscari) and camellia (Camellia japonica). Fausey (2003) found that flumioxazin, oxyfluorfen, pelargonic acid, acetic acid, and oxadiazon provided acceptable preemergence and/or postemergence liverwort and moss control; however, no product provided acceptable control of these weeds at all evaluations. Finding crops that are tolerant of postemergence herbicides would be very beneficial for growers. Preemergence herbicides are a "blind" control method. How is one to know if weed seeds are even present or are going to emerge in a given time frame? The weed species present may not even be in the control spectrum of the herbicide. With postmergence herbicides, it is possible to see what species are present, where they are problematic, and when you have to apply the herbicide. There needs to more research in this area, as there are many postemergence herbicides with many different modes of action and weed control spectrums.

\section{Factors affecting herbicide activity and fate in the environment}

Five factors influence herbicide activity and therefore herbicide choice. First is the influence of microbial breakdown. Most herbicides are broken down by microbes at some point in time. Herbicide chemical structure determines the ease and rate of its breakdown by microbes. Microbes "eat" what is more available and easy for them to break down, which are usually things like fertilizers and organic matter. Some herbicides like 2,4-D decompose quickly, with an average half-life of $10 \mathrm{~d}$ (Vencill, 2002). Compounds like diuron and atrazine are more resistant to microbial breakdown and can persist longer than one year; degradation rate is highly dependent on the $\mathrm{pH}$ of the soil. Repeated applications of the same herbicide can lead to a buildup of microbes that are particularly good at breaking down that herbicide, which can lead to a decrease in residual activity (Altland, 2003).

Secondly, adsorption influences 
Table 2. A partial list of herbicides registered for use in outdoor ornamentals and non-crop areas. Chemical families marked with the same herbicide resistance activity code (HRAC) have been shown to result in cross-resistance among weed species (Altland, 2003b; Prather et al. 2000; Vencill, 2002).

\begin{tabular}{|c|c|c|c|c|c|c|}
\hline HRAC & $\begin{array}{l}\text { Mode of } \\
\text { action }\end{array}$ & Herbicide family & \begin{tabular}{|l|} 
Common \\
name of active \\
ingredient
\end{tabular} & $\begin{array}{l}\text { Trade name(s) and } \\
\text { areas of application }\end{array}$ & $\begin{array}{l}\text { Application } \\
\text { timing }^{\mathrm{y}}\end{array}$ & $\begin{array}{l}\text { Primary } \\
\text { types of } \\
\text { weeds } \\
\text { controlled }\end{array}$ \\
\hline \multirow[t]{3}{*}{$B$} & $\begin{array}{l}\text { Amino acid } \\
\text { synthesis } \\
\text { inhibitor (ALS } \\
\text { inhibitor }\end{array}$ & Imidazolinone & imazapic & $\begin{array}{l}\text { Plateau: some } \\
\text { wildflowers and } \\
\text { grasses, non-crop } \\
\text { areas }\end{array}$ & Pre, Post & Grasses \\
\hline & & & imazaquin & $\begin{array}{l}\text { Image: selected } \\
\text { ornamentals }\end{array}$ & Pre, Post & $\begin{array}{l}\text { Grasses, } \\
\text { broadleaf } \\
\text { weeds }\end{array}$ \\
\hline & & Sulfonylurea & halosulfuron & $\begin{array}{l}\text { Manage, Sempra: } \\
\text { established } \\
\text { ornamentals and turf }\end{array}$ & Post & $\begin{array}{l}\text { Broadleaf } \\
\text { weeds, } \\
\text { sedges }\end{array}$ \\
\hline G & \begin{tabular}{|l|} 
Amino acid \\
synthesis \\
inhibitor (EPSP \\
synthase \\
inhibitor)
\end{tabular} & Glycine & glyphosate & $\begin{array}{l}\text { Rattler, Roundup } \\
\text { (various), Prosecutor: } \\
\text { non-crop areas, } \\
\text { glyphosate-tolerant } \\
\text { species (e.g., RR } \\
\text { bentgrass) }\end{array}$ & Post & $\begin{array}{l}\text { Grasses, } \\
\text { broadleaf } \\
\text { weeds }\end{array}$ \\
\hline \multirow[t]{2}{*}{$\mathrm{L}$} & $\begin{array}{l}\text { Cell wall } \\
\text { synthesis } \\
\text { inhibitor }\end{array}$ & Benzamide & isoxaben & $\begin{array}{l}\text { Gallery: field and } \\
\text { container stock, } \\
\text { established turf, } \\
\text { conifers, certain } \\
\text { perennials }\end{array}$ & Pre & $\begin{array}{l}\text { Broadleaf } \\
\text { weeds }\end{array}$ \\
\hline & & Nitrile & dichlobenil & $\begin{array}{l}\text { Casoron: selected } \\
\text { ornamentals }\end{array}$ & Pre & $\begin{array}{l}\text { Grasses, } \\
\text { broadleaf } \\
\text { weeds }\end{array}$ \\
\hline \multirow[t]{3}{*}{$\mathrm{D}$} & $\begin{array}{l}\text { Cell membrane } \\
\text { disrupter } \\
\text { (inhibits PS I) }\end{array}$ & Bipyridylium & $\begin{array}{l}\text { diquat } \\
\text { dibromide }\end{array}$ & $\begin{array}{l}\text { Reward L\&A: non-crop } \\
\text { areas }\end{array}$ & Post & $\begin{array}{l}\text { Grasses, } \\
\text { broadleaf } \\
\text { weeds }\end{array}$ \\
\hline & & & paraquat & $\begin{array}{l}\text { Starfire: non-crop } \\
\text { areas }\end{array}$ & Post & $\begin{array}{l}\text { Grasses, } \\
\text { broadleaf } \\
\text { weeds }\end{array}$ \\
\hline & & Oxadiazole & oxadiazon & $\begin{array}{l}\text { Ronstar, Promate } \\
\text { Ronstar: established } \\
\text { turf and selected } \\
\text { woody ornamentals } \\
\text { and conifers }\end{array}$ & Pre & Grasses \\
\hline \multirow[t]{2}{*}{$\mathrm{E}$} & $\begin{array}{l}\text { Cell membrane } \\
\text { disruptor } \\
\text { (inhibits PPO } \\
\text { enzyme) }\end{array}$ & Diphenyl ether & oxyfluorfen & $\begin{array}{l}\text { Goal, Galigan: } \\
\text { conifers, selected } \\
\text { ornamentals, field and } \\
\text { container }\end{array}$ & Pre & $\begin{array}{l}\text { Broadleaf } \\
\text { weeds }\end{array}$ \\
\hline & & $\mathrm{N}$-phenylphthalamide & flumioxazin & $\begin{array}{l}\text { Sureguard, BroadStar: } \\
\text { conifers, selected } \\
\text { ornamentals }\end{array}$ & Pre, Post & $\begin{array}{l}\text { Broadleaf } \\
\text { weeds }\end{array}$ \\
\hline \multirow[t]{3}{*}{$A$} & $\begin{array}{l}\text { Fatty acid } \\
\text { synthesis } \\
\text { inhibitor }\end{array}$ & Aryloxyphenoxy-propionate & fluazifop-p-butyl & $\begin{array}{l}\text { Fusilade II: dicot } \\
\text { ornamentals, conifers }\end{array}$ & Post & Grasses \\
\hline & & & fenoxaprop & $\begin{array}{l}\text { Acclaim Extra: dicot } \\
\text { ornamentals, conifers, } \\
\text { turf }\end{array}$ & Post & Grasses \\
\hline & & Cyclohexanediones & clethodim & $\begin{array}{l}\text { Envoy, Arrow: dicot } \\
\text { ornamentals, conifers }\end{array}$ & Post & Grasses \\
\hline $\mathrm{O}$ & $\begin{array}{l}\text { Growth } \\
\text { regulator }\end{array}$ & Phenoxy-carboxylic acid & 2,4-D ester & $\begin{array}{l}\text { Weedone, Esteron, } \\
\text { Barrage, Turret: turf } \\
\text { and non-crop areas }\end{array}$ & Post & $\begin{array}{l}\text { Broadleaf } \\
\text { weeds }\end{array}$ \\
\hline
\end{tabular}

Table 2 continued on next page. 
Table 2. Continued from previous page.

\begin{tabular}{|c|c|c|c|c|c|c|}
\hline HRAC & $\begin{array}{l}\text { Mode of } \\
\text { action }^{2}\end{array}$ & Herbicide family & $\begin{array}{l}\text { Common } \\
\text { name of active } \\
\text { ingredient }\end{array}$ & $\begin{array}{l}\text { Trade name(s) and } \\
\text { areas of application }\end{array}$ & \begin{tabular}{|l|}
$\begin{array}{l}\text { Application } \\
\text { timing }^{y}\end{array}$ \\
\end{tabular} & $\begin{array}{l}\text { Primary } \\
\text { types of } \\
\text { weeds } \\
\text { controlled }\end{array}$ \\
\hline & & & 2,4-D amine & $\begin{array}{l}\text { Dri Clean, Formula 40, } \\
\text { Opti-amine, Solution } \\
\text { Water Soluble, } \\
\text { Weedestroy: turf and } \\
\text { non-crop areas }\end{array}$ & Post & $\begin{array}{l}\text { Broadleaf } \\
\text { weeds }\end{array}$ \\
\hline & & Benzoic acid & dicamba & $\begin{array}{l}\text { Banvel, Vanquish: turf } \\
\text { and noncrop areas }\end{array}$ & Post & $\begin{array}{l}\text { Broadleaf } \\
\text { weeds }\end{array}$ \\
\hline & & Pyridine carboxylic acid & triclopyr & $\begin{array}{l}\text { Turflon: non-crop } \\
\text { areas }\end{array}$ & Post & $\begin{array}{l}\text { Broadleaf } \\
\text { weeds }\end{array}$ \\
\hline & & & clopyralid & $\begin{array}{l}\text { Lontrel T\&O: turf, } \\
\text { established selected } \\
\text { trees, ornamentals, } \\
\text { grasses }\end{array}$ & Post & $\begin{array}{l}\text { Broadleaf } \\
\text { weeds }\end{array}$ \\
\hline $\mathrm{H}$ & $\begin{array}{l}\text { Glutamine } \\
\text { synthesis } \\
\text { inhibitor }\end{array}$ & Phosphonic acid & glufosinate & Finale: non-crop areas & Post & $\begin{array}{l}\text { Grasses, } \\
\text { broadleaf } \\
\text { weeds }\end{array}$ \\
\hline \multirow[t]{2}{*}{$\mathrm{C}_{1}$} & $\begin{array}{l}\text { Mobile PS II } \\
\text { inhibitor }\end{array}$ & Triazine & atrazine & $\begin{array}{l}\text { Atrazine, Atra-5: turf, } \\
\text { newly transplanted or } \\
\text { established conifers } \\
\text { before bud break }\end{array}$ & Pre, Post & $\begin{array}{l}\text { Grasses, } \\
\text { broadleaf } \\
\text { weeds }\end{array}$ \\
\hline & & & simazine & $\begin{array}{l}\text { Princep, Simtrol: } \\
\text { conifers }\end{array}$ & Pre & $\begin{array}{l}\text { Grasses, } \\
\text { broadleaf } \\
\text { weeds }\end{array}$ \\
\hline $\mathrm{C}_{2}$ & $\begin{array}{l}\text { Mobile PS II } \\
\text { inhibitor } \\
\text { (different } \\
\text { binding site } \\
\text { than triazines) }\end{array}$ & Urea & diruon & $\begin{array}{l}\text { Diuron: established } \\
\text { trees }\end{array}$ & Pre & $\begin{array}{l}\text { Broadleaf } \\
\text { weeds }\end{array}$ \\
\hline 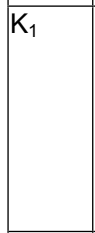 & $\begin{array}{l}\text { Mitotic } \\
\text { disruptors; } \\
\text { microtubule } \\
\text { assembly } \\
\text { inhibitors (root } \\
\text { meristem } \\
\text { inhibitors) } \\
\end{array}$ & Pyridine & dithiopyr & $\begin{array}{l}\text { Dimension, Pro-mate } \\
\text { Dimension: selected } \\
\text { ornamentals and } \\
\text { conifers, turf }\end{array}$ & Post & $\begin{array}{l}\text { Grasses, } \\
\text { broadleaf } \\
\text { weeds }\end{array}$ \\
\hline $\mathrm{C}_{3}$ & $\begin{array}{l}\text { Non-mobile } \\
\text { photosynthetic } \\
\text { inhibitor (inhibit } \\
\text { PS II) }\end{array}$ & Benzothidazole & bentazon & $\begin{array}{l}\text { Basagran, Lescogran: } \\
\text { established turf, } \\
\text { selected ornamentals, } \\
\text { non-crop areas }\end{array}$ & Post & $\begin{array}{l}\text { Broadleaf } \\
\text { weeds }\end{array}$ \\
\hline \multirow[t]{3}{*}{$\mathrm{K}_{1}$} & $\begin{array}{l}\text { Mitotic } \\
\text { disruptors; } \\
\text { microtubule } \\
\text { assembly } \\
\text { inhibitors (root } \\
\text { meristem } \\
\text { inhibitors) }\end{array}$ & Dinitroaniline & prodiamine & $\begin{array}{l}\text { Barricade Endurance, } \\
\text { Pro-mate Barricade: } \\
\text { selected ornamentals } \\
\text { and conifers, } \\
\text { established turf }\end{array}$ & Pre & Grasses \\
\hline & & & pendimethalin & $\begin{array}{l}\text { Pendulum Aquacap, } \\
\text { Pendulum 2G, Pre-M: } \\
\text { selected ornamentals } \\
\text { and conifers, } \\
\text { established turf }\end{array}$ & Pre & Grasses \\
\hline & & & oryzalin & $\begin{array}{l}\text { Surflan, Oryzalin 4AS: } \\
\text { selected ornamentals, } \\
\text { conifers, established } \\
\text { turf }\end{array}$ & Pre & Grasses \\
\hline
\end{tabular}

Table 2 continued on next page. 
Table 2. Continued from previous page.

\begin{tabular}{|c|c|c|c|c|c|c|}
\hline HRAC & $\begin{array}{l}\text { Mode of } \\
\text { action }^{2}\end{array}$ & Herbicide family & \begin{tabular}{|l|} 
Common \\
name of active \\
ingredient
\end{tabular} & $\begin{array}{l}\text { Trade name(s) and } \\
\text { areas of application }\end{array}$ & \begin{tabular}{|l|}
$\begin{array}{l}\text { Application } \\
\text { timing }^{y}\end{array}$ \\
\end{tabular} & $\begin{array}{l}\text { Primary } \\
\text { types of } \\
\text { weeds } \\
\text { controlled }\end{array}$ \\
\hline & & & trifluralin & $\begin{array}{l}\text { Treflan, Bayonet, } \\
\text { Trifluralin, Triflurex: } \\
\text { selected ornamentals, } \\
\text { conifers, established } \\
\text { turf }\end{array}$ & Pre & Grasses \\
\hline \multirow[t]{3}{*}{$\mathrm{K}_{3}$} & \begin{tabular}{|l|} 
Cell division \\
inhibitor \\
(seedling shoot \\
inhibitor)
\end{tabular} & Acetamide & napropamide & $\begin{array}{l}\text { Devrinol (2G, 50DF): } \\
\text { selected ornamentals, } \\
\text { conifers, and turf }\end{array}$ & Pre & $\begin{array}{l}\text { Grasses, } \\
\text { broadleaf } \\
\text { weeds }\end{array}$ \\
\hline & & Choroacetamide & metolachlor & $\begin{array}{l}\text { Pennant Magnum: } \\
\text { selected ornamentals, } \\
\text { turf }\end{array}$ & Pre & $\begin{array}{l}\text { Sedges, } \\
\text { grasses }\end{array}$ \\
\hline & & Benzamide & pronamide & $\begin{array}{l}\text { Kerb: selected } \\
\text { ornamentals, conifers }\end{array}$ & Pre & $\begin{array}{l}\text { Winter } \\
\text { annuals }\end{array}$ \\
\hline
\end{tabular}

${ }^{\mathrm{z} A L S}=$ acetolactate synthase, EPSP $=5$-enolpyruvylshikimate- 3 -phosphate, PS I = photosystem I, PPO = protoporphyrinogen oxidase, PS II = photosystem II.

${ }^{\mathrm{x}}$ Pre $=$ preemergence ; post $=$ postemergence .

herbicide activity and refers to the chemical and/or physical attraction of a substance to a surface. Soil organic matter content and $\mathrm{pH}$ have a profound impact on adsorption. The high organic matter content found in soilless container mixes has tremendous adsorptive capacity (J.G. Graveel and R.F. Turco, personal communication). Herbicide adsorption depends to a great extent on the herbicide chemical properties. Dinitroaniline herbicides are strongly adsorbed to nursery mixes with normal pH (J.G. Graveel and R.F. Turco, personal communication).

The third factor is leaching, the movement of a herbicide in solution through the soil. Although non-target loss is the largest contributor of herbicide runoff (Keese et al., 1994), leaching also comes into effect. Groundwater contamination and herbicide runoff into recirculation ponds have increased the nursery industry's awareness of an herbicide's leaching potential. About $7.3 \%$ of the total amount of isoxaben applied was found in runoff water from a spray application within $8 \mathrm{~d}$ of application (Riley, 2003). Leaching ability of a particular herbicide is dependent on the water solubility of the chemical (Riley et al., 1994; Riley, 2003), porosity of the media (Mahnken et al., 1994), and the affinity of the media to adsorb the chemical (Horowitz and Elmore, 1991; Mahnken et al., 1994; Rouchaud et al., 1999). Leaching ability is also affected by amount of irrigation/rainfall immediately after herbicide treatment (Horowitz and Elmore, 1991; Riley et al., 1994) and foliage (the crop canopy affects particle
placement)(Landis et al., 1991). A study using radio-labeled oxadiazon found that $5.4 \%$ of the chemical could be leached in a 5 -d period after it was applied to container plants (Wehtje et al., 1993). Judge et al. (2002) found trifluralin loss was greatest by $7 \mathrm{~d}$ after treatment in an aged pine bark:sand (7:1) substrate. In a column leaching study, Horowitz and Elmore (1991) reported that increasing oxyfluorfen concentration from 20 to $200 \mathrm{ppm}$ exceeded the bioassay sensitivity along the column of media, indicating oxyfluorfen was leaching. Mahnken et al. (1994) studied the leaching of simazine and metolachlor and found that leaching of these two herbicides was most severe with a 3:1 redwood bark: sand medium. Recent studies have indicated that the application of preemergent herbicides onto organic mulches reduced herbicide leaching by $35-74 \%$ compared with bare soil preemergent herbicide applications (Knight et al., 2001), probably because of increased adsorption by the organic content of the mulch.

The fourth factor that affects herbicide activity is volatility, the tendency of the herbicide to change from a solid or liquid to the gaseous phase. Some herbicides can volatilize and are lost to the atmosphere. Some examples of volatile ornamental herbicides include the preemergent herbicides trifluralin (a dinitroaniline herbicide) and oxyfluorfen. Examples of postemergent herbicides that are highly volatile are growth regulators such as 2,4-D or dicamba. Some herbicides such as atrazine and imazaquin, are not con- sidered volatile compounds; however, they can evaporate over a period of time, if hot and dry conditions prevail. Volatile herbicides are lost more readily from moist soils than from dry soils. If sensitive species are in proximity to the volatile compounds, they can be damaged. When using volatile herbicides, one should take more caution with environmental factors like heat, wind, and humidity.

The final factor is photodecomposition. Many herbicides are not highly susceptible to photodecomposition, but it can occur over time and can be an issue in container production where herbicides can be exposed on the media surface for longer periods of time than in field culture. Dinitroaniline herbicides like trifluralin, oryzalin, pendimethalin and prodiamine are susceptible to photodecomposition (Vencill, 2002). Oxyfluorfen, another common container preemergent herbicide, is also susceptible to photodecomposition (Vencill, 2002).

Problems associated with herbicide use in container production include proper calibration, herbicide runoff concerns from plastic or gravel (especially when chemicals fall between containers), and the need for multiple applications. Frequent reapplication is necessary to maintain acceptable weed control in containers, so it is likely that the adsorption and half-life of herbicides on the surface of a soilless media is less than those observed in field soils (Judge et al., 2002). Off-site movement of herbicides through leaching, runoff, and spray drift is a concern facing nursery growers. As much as $80 \%$ 
of a granular applied herbicide can be lost by non-target losses, depending on pot spacing (Gilliam et al., 1992). There were only slight differences in herbicide losses depending on crop species present (Gilliam et al., 1992). Non-uniformity is also a concern when applying herbicides. Properly trained personnel and calibrated and well-maintained equipment can reduce non-uniformity. Growers also need to be aware of the best procedures and techniques to apply herbicides to reduce the loss from non-uniformity and misapplication. Extension agents should be aware of these procedures and teach them to the growers. Possibly the biggest problem with herbicide use is human exposure and environmental issues.

Within the last 10 to 20 years, environmental fate of herbicides has become a major issue. Even though many health tests are required for registration of a pesticide by the U.S. Environmental Protection Agency (EPA), the potential long-term human toxicological effects of herbicides are not fully understood, and probably never could be because of the complexities between bodily processes and pesticides. However, we can estimate herbicide acute and chronic toxicities to humans through the use of laboratory animals. Oxadiazon, a common nursery herbicide, is likely to be an oncogen (i.e., a substance that can cause the production of tumors), and has slight to moderate acute mammalian toxicity (Mattern et al., 1991). Many environmental fate studies have been conducted with herbicides in agronomic crops. Few studies, however, have been conducted on herbicide fate in the nursery area. EPA requires extensive reporting from laboratory and field studies about the environmental fate of new pesticides (Winton and Weber, 1996). The Food Quality and Protection Act of 1996 also requires that old pesticides be re-registered.

Pesticides applied to containers can be lost through misapplication or by leaching of the pesticides out of the bottom of the pot (Horowitz and Elmore, 1991; Keese et al., 1994). Containment (or recirculation) ponds catch much of the runoff from rain and irrigation water, which may hold herbicide residue. Recirculation ponds are ponds that are used to irrigate the nursery area and designed to catch $90 \%$ of the water after each irrigation event and a maximum of $40 \%$ of irrigation water from multiple applications (Mathers, 2002b). These ponds can catch some of the herbicides that are lost due to leaching and misapplication (Keese et al., 1994; Riley et al. 1994). This is of concern since the herbicides present in the ponds could be phytotoxic to some of the crops when they are irrigated with the water from the ponds (Horowitz and Elmore, 1991).

\section{Reducing herbicide runoff}

Herbicide losses from containers used in ornamental horticulture can be reduced by effective management strategies and with new, innovative ideas. Some ideas have been implemented and used by nurseries; some have not. One way, of course, it to implement hand weeding as the primary method of weed control, however, this is quite expensive compared to chemical control. As previously mentioned, non-target loss is a major contributor to herbicide runoff. Reducing pot spacing when applying herbicides can reduce herbicide loss (Gilliam et al, 1992).

Herbicides have been combined with different "carriers" to reduce the amount of herbicide applied. Herbicides have been combined with different carriers for four purposes: 1 ) to reduce the amount of herbicide needed (Derr, 1994); 2) to enhance and/or extend efficacy (Derr, 1994); 3) to increase environmental and ecological safety; and, 4) to avert some current label restrictions (Mathers and Ozkan, 2001). Controlled-released fertilizers coated with oxadiazon were effective at suppressing prostrate spurge and large crabgrass (Crossan et al., 1997). A dicalcium phosphate tablet coated with propachlor, alachlor, naptalam, or chloramben provided good weed control when the right number of tablets were placed in the right sized containers (Ruizzo et al., 1983). The tablets released a small amount of herbicide whenever water was applied. In a later study, surfactants were added to the tablets containing one of the following: metolachlor, isoxaben, oryzalin, oxadiazon, or oxyflourfen. The best combination was oxyflourfen + X-77 (United Agri Products, Greeley, Colo.), and the area of weed inhibition was further increased up to 15 $\mathrm{cm}$ around the tablet (Horowitz et al., 1990). Koscelny and Peeper (1996) found that when chlorsulfuron and triasulfuron were impregnated into double ammonium phosphate fertilizer, the control of henbit (Lamium amplexicaule) and bushy wallflower (Erysimum repandum) was as good or better as the directed sprays of the herbicides, depending on herbicide and weed species.

One idea researched by Mathers in 1998 and 2000 involved combining herbicides with mulches. The thinking was that the herbicide would adsorb to the mulch, causing the herbicide to be released slowly into the soil or media. This, in turn, would decrease the amount of herbicide needed and reduce the amount leached from the each pot. Mathers (2003) compared the efficacy of various mulches to herbicide-treated mulches. The herbicide-treated mulch that was most effective in the 1998 and 2000 study was douglas fir (Pseudotsuga menziesii) nuggets treated with oryzalin. Mathers found that the herbicide-treated douglas fir increased and extended efficacy and reduced phytotoxicity compared to the herbicides applied alone, and speculated they would help reduce herbicide movement and non-target losses. Cultural control and chemical control can be used simultaneously to control weeds. More research is needed in this area, because the evidence presented here indicates herbicide residual can be extended and weed control increased. There are also possibilities of using herbicides that are not normally used with nursery crops. Mathers et al. (2004) found that acetochlor when combined with pine nuggets or hardwood is not injurious to 'Care Free Beauty' rose (Rosa spp.) or 'Green Gem' boxwood (Buxus spp.), and hardwood combined with acetochlor is only slightly phytotoxic to 'Little Princess' spirea (Spirea spp.).

\section{Herbicide technology and research}

There are many herbicides, herbicide manufacturers, and many crops in the nursery/ornamental industry. One can see that there is always research to be done, especially with the large amount of species. Interregional Research Project \#4 (IR-4) was established in 1963 to obtain regulatory clearances for crop protection chemicals on specialty food crops (IR-4, 2004). Nursery, floral, Christmas trees, forestry, and turf crops were added to the program in 1977. Many herbicides are now registered for ornamental crops through the IR-4 
program. IR- 4 is administered by the U.S. Department of Agriculture and Cooperative State Research Education and Extension Service. A pesticide is registered for a specific crop after the pesticide's manufacturer deems there is enough data to support the registration; the data comes from the collaborative efforts of many researchers (mostly from universities) across the nation (IR-4, 2004).

Potential new pesticides are one research focus of many pesticide manufacturers, and there are usually new chemicals every year. Many of these chemicals go through the IR-4 program for ornamentals due to the extensive amount of species. Chemical companies cannot afford to test each species. Although new chemicals cost a lot of money to register, the monetary gain by the manufacturer and growers (indirectly by using the pesticide) is a huge incentive for companies to look for new chemistry. New formulations to existing herbicides are also researched. Many herbicides are now being micro-encapsulated by the manufacturer to improve residual [e.g., Pendulum Aquacap (BASF, Research Triangle Park, N.C.) and Degree (Monsanto Corp., St. Louis)]. Also, whenever a new chemistry is found, many types of formulations (e.g., wettable powder, granular, emulsifiable concentrate, etc.) are researched, along with herbicide concentrations in each formulation.

Glyphosate-tolerant crops are now quite extensive, ranging from glyphosate-tolerant soybeans to glyphosate-tolerant bentgrass (Agrostis stolonifera) (AGBIOS, 2004), which is approved for use as animal feeding. As of right now, there are no glyphosatetolerant nursery crops approved for use (AGBIOS, 2004). As already stated, glyphosate tolerance (or resistance) in weeds is not desirable, however, in crops, this can be highly desirable because of the wide range of weed control that glyphosate can give. Glyphosate tolerance in the most desirable crops would be one way of postemergence control of problem weeds. Glyphosate is also relatively cheap in comparison to many preemergence herbicides, so this would save growers much money directly and indirectly (e.g., only applying glyphosate where it is needed). Crops have been genetically altered for other herbicides also, such as glufosinate and imadizolinone herbicides (AGBIOS,
2004). Glyphosate tolerance is just one of the possibilities. Although there is some worldwide concern on genetically modified crops, these do present a very wide field of research for nursery crops.

\section{Conclusion}

Controlling weeds is an important aspect of container nurseries. Weed scouting, using good sanitary methods, sprayer calibration, and herbicidal knowledge are key points in starting a weed control program. Other points to consider when trying to control weeds are worker safety, the environment, and economical costs of the program. Using the correct herbicide at the right time while reducing herbicide loss to surface water, recirculation ponds, etc. will be economical for the nursery and will also be environmentally friendly. Keeping up with new advances, technology, and herbicides will also be advantageous for the grower. With the increasing amount of concern for the environment and the reduction of new herbicide registrations, there is a continued need for new ideas and innovations to control weeds, although the suggestions presented in this paper could resolve some of the issues.

\section{Literature cited}

Abbey, T.M., T.L. Mervosh, A.F. Senesac, and I.T. Bradley. 2001. Mulches for weed suppression in containers of herbaceous perennials. Perennial Plant Assn. Qrtly. J. Autumn:9-24.

AGBIOS. 2004. GM Database. 11 Jan. 2005. <http://www.agbios.com/dbase. php?action=synopsis $>$.

Ahn, J.K. and I.M. Chung. 2000. Allelopathic potential of rice hulls on germination and seedling growth of barnyardgrass. Agron. J. 92(6):1162-1167.

Altland, J.E., C.H. Gilliam, J.W. Olive, and J.H. Edwards. 2000a. Postemergence control of bittercress in container-grown crops. J. Environ. Hort. 18(1):23-28.

Altland, J.E., C.H. Gilliam, J.H. Edwards, G.J. Keever, J.R. Kessler, Jr., and D.J. Eakes. 2000b. Effect of bittercress size and gallery rate on postemergence bittercress control. J. Environ. Hort. 18(3):128-132.

Altland, J.E. 2002. Herbicide timing for container weed control. Digger 46:46-48.

Altland, J. 2003. Be aware of herbicide residues in field soils. Digger 47:48-53.

Altland, J.E., C.H. Gilliam, and G. Wehtje. 2003. Weed control in field nurseries. HortTechnology 13(1):9-14.
Altland, J.E. 2004. Container substrate particle size affects pearlwort growth. Proc. Northeast Weed Sci. Soc. 58:52-53.

Appleton, B.L. and S.C. French. 2000. Weed suppression for container-grown willow oak using copper-treated fabric disks. Hort Technology 10(1):204-206.

Ashton F.M and A.S. Crafts. 1981. Mode of action of herbicides. 2nd ed. Wiley, New York.

Berchielli-Robertson, D.L., C.H. Gilliam, and D.C. Fare. 1990. Competitive effects of weeds on the growth of container-grown plants. HortScience 25(1):77-79.

Billeaud, L.A. and J.M. Zajicek. 1989. Influence of mulches on weed control, soil pH, soil nitrogen content, and growth of Ligustrum japonicum. J. Environ. Hort. 7(4):155-157.

Briggs, J., T. Whitwell, M. B. Riley, R. Smith, and G. Legnani. 2001. Preemergent bittercress control on a gravel groundcover. J. Environ. Hort. 19(2):104-108.

Cranston, R. 1994. Weed control: An introductory manual. British Columbia Ministry of Agr., Fisheries and Food, Abbottsford.

Cross, G.B., and W.A. Skroch. 1992. Quantification of weed seed contamination and weed development in container nurseries. J. Environ. Hort. 10(3):159-161.

Crossan, C.K., C.H. Gilliam, G.J. Keever, D.J. Eakes, G.R. Wehtje, and W.A. Dozier, Jr. 1997. Weed control in container-grown crops with herbicide coated fertilizers. J. Environ. Hort. 15(3):138-141.

Darden, J. and J.C. Neal. 1999. Granular herbicide application uniformity and efficacy in container nurseries. Proc. Southern Nursery Assn. Res. Conf. 44:427-430.

DeGennaro, F.P. and S.C. Weller. 1984. Differential susceptibility of field bindweed (Convolvulus arvensis) biotypes to glyphosate. Weed Sci. 32(4):472-476.

Derr, J.F. 1994. Weed control in containergrown herbaceous perennials. HortScience 29:95-97.

Derr, J.F. and S. Salihu. 1996. Preemergence herbicide effects on nursery crop root and shoot growth. J. Environ. Hort. 14(4):210-213.

Elmore, C.L. and C.A. Wilen. 2000. Floriculture and ornamental nurseries container nurseries. 1 Oct. 2004. <www.ipm.ucdavis.edu/pmg/ r280701211.html>.

Fausey, J.C. 2003. Controlling liverwort and moss now and in the future. HortTechnology 13:35-38.

Fretz, T.A. 1972. Weed competition in container-grown japanese holly. HortScience $7: 485-486$.

Gilliam, C.H., W.J. Foster, J.L. Adrain, and R.L. Shumack. 1990. A survey of weed control costs and strategies in container production nurseries. J. Environ. Hort. 8(3):133-135.

Gilliam, C.H., D.C. Fare, and A. Beasley. 1992. Nontarget herbicide losses from application of granular Ronstar to container nurseries. J. Environ. Hort. 10(3):175-176. 
Hall, L., H. Beckie, and T.M. Wolf. 1999. How herbicides work: Biology to application. Alberta Agr., Food And Rural Dev., Edmonton.

Hager, A., L. Wax, M. McGlamery, and D. Pike. 1998. Herbicide resistance in weeds. Univ. of Illinois Ext. 15 Nov. 2004. <http://www. weedresearch.com/articles/5049.htm>.

Heap, I., N. DiNicola, L. Glasglow. 2004. Official WSSA definitions of "herbicide resistance" and "herbicide tolerance." 7 Dec. 2004. <http://www.weedscience.org/paper/definitions.htm>.

Hobbs, H.A., R.R. Johnson, R.N. Story, and L.L. Black. 1996. Weed hosts and thrips transmission of tomato spotted wilt virus in Louisiana. Acta Hort. 431:291-297.

Horowitz, M., E. Smith, and S.F. Gorski. 1990. Feasibility of adding surfactants to slow-release herbicide tablets for container-grown plants. J. Environ. Hort. 8(1):36-41.

Horowitz, M. and C.L. Elmore. 1991. Leaching of oxyfluorfen in container media. Weed Technol. 5(1):175-180.

IR-4. 2004. IR-4 A program review. 10 Jan. 2005. <http://ir4.rutgers.edu/binars/ir-4programoverview.pdf $>$.

Judge, C.A., J.C. Neal, and R.B. Leidy. 2002. Trifluralin dissipation in a bark-based substrate. Proc. Southern Nursery Assn. Res. Conf. 47:389-392.

Keese, R.J., N.D. Camper, T. Whitwell, M.B. Riley, and P.C. Wilson. 1994. Herbicide runoff from ornamental container nurseries. J. Environ. Qual. 23(2):320-324.

Knight, P.R., C.H. Gilliam, S.L. File, and D. Reynolds. 2001. Mulches reduce herbicide loss in the landscape. Proc. Southern Nursery Assn. Res. Conf. 46:461-463.

Koscelny, J.A. and T.F. Peeper. 1996. Herbicides impregnated onto granular fertilizer carriers for broadleaf weed control in winter wheat (Triticum aestivum). Weed Technol. 10(3):526-530.

Lal, R. 2002. Mulch farming. p. 844-850. In: R. Lal (ed.). Encyclopedia of soil science. Marcel Dekkar, New York.

Landis, T.D., S. Campbell, and F. Zensen. 1991. Agricultural pollution of surface water and groundwater in forest nurseries. Proc. Intermountain For. Nursery Assn. USDA Tech. Rep. RM-211.

Loux, M.M., J.M. Stachler, and S.K. Harrison. 2002. Weed control guide for ohio field crops. Ohio State Univ. Ext. Bul. 789.

Mahnken, G.E., W.A. Skroch, T.J. Sheets, and R.B. Leidy. 1994. Metolachlor and simazine leaching through horticultural substrates. J. Environ. Hort. 12(1):55-58.

Mallory-Smith, C., D. Thill, and D. Morishita. 1999. Herbicide-resistant weeds and their management. Pacific Northwest Ext. Bul. 437(rev.).

Mathers, H. and E. Ozkan. 2001. Herbicide treated mulches. Nursery Mgt. Production. 17(1):61-64, 66.
Mathers, H. 2002a. Uncovering the truth about mulches. The Buckeye. September.

Mathers, H. 2002b. Nursery irrigation. Amer. Nurseryman 196(10):22-24, 26-29.

Mathers, H. 2003. Novel methods of weed control in containers. HortTechnology 13(1):28-31.

Mathers, H.M., J. Pope, and L.T. Case. 2004. Evaluation of micro-encapsulated herbicides alone and applied to bark mulches. Proc. Northeast Weed Sci. Soc. 58:47.

Mattern, G.C., C-H Liu, J.B. Louis, and J.D. Rosen. 1991. GC/MS and LC/MS determination of 20 pesticides for which dietary oncogenic risk has been estimated. J. Agr. Food Chem. 39(4):700-704.

Mervosh, T.L. and J.F. Ahrens. 1998. Preemergence herbicides for container-grown perennials. Proc. Northeastern Weed Sci. Soc. 52:131.

Morejohn, L.C., T.E. Bureau, J. Mole-Bajer, A.S. Bajer, and D.E. Fosket. 1987. Oryzalin, a dinitroaniline herbicide, binds to plant tubulin and inhibits microtubule polymerization in vitro. Planta 172:252-264.

Neal, J. 1999. Weeds and you. Nursery Mgt. Production 15(1):60-62, 64-65.

Norcini, J.G. and R.H. Stamps. 1994. Container nursery weed control. Florida Coop. Ext. Serv., Inst. Food and Agr. Serv., Univ. of Florida. Circ. 678.

Powles, S. and J. Matthews. 1992. Multiple herbicide resistance in annual ryegrass (Lolium rigidum): A driving force for the adoption of integrated weed management, p. 75-87. In: I. Denholm, A. Devonshire, and D. Holloman (eds.). Achievements and developments in combating pest resistance. Elsevier, London.

Prather, T.S., J.M. Ditomaso, and J.S. Holt. 2000. Herbicide resistance: definition and management strategies. Univ. of California Div. Agr. and Natural Resources. Pub. 8012.

Pratley, J., N. Urwin, R. Stanton, P. Baines, J. Broster, K. Cullis, D. Schafer, J. Bohn, and R. Krueger. 1999. Resistance to glyphosate in Lolium rigidum I. bioevaluation. Weed Sci. 47(4):405-411.

Riley, M.B., R.J. Keese, N.D. Camper, T. Whitwell, and P.C. Wilson. 1994. Pendimethalin and oxyfluorfen residues in pond water and sediment from container plant nurseries. Weed Technol. 8(2):299-303.

Riley, M.B. 2003. Herbicide losses in runoff of containerized plant production nurseries. HortTechnology 13:16-22.

Robinson, D.W. 1988. Mulches and herbicides in ornamental plantings. HortScience 23:547-552.

Ross, M.A. and D.J. Childs. 1996. Herbicide mode of action summary. Coop. Ext. Serv. Purdue Univ. 14 Apr. 2004. <http://www. agcom/purdue.edu/agcom/pubs/ws/ws23.html>
Ross, M.A., and C.A. Lembi. 1999. Applied weed science, 2nd ed. Prentice Hall, Upper Saddle River, N.J.

Rouchaud, J., O. Neus, M.C. Van Labeke, K. Cools, and R. Bulcke. 1999. Isoxaben and BAS $47914 \mathrm{H}$ retention/loss from peat substrate of nursery plants. Weed Sci. 47(5):602-607.

Ruizzo, M.A., E.M. Smith, and S.F. Gorske. 1983. Evaluations of herbicides in slow-release formulations for container-grown landscape crops. J. Amer. Soc. Hort. Sci. 108(4):551553.

Ryan, G.F. 1977. Multiple herbicide application for bittercress control in nursery containers. HortScience 12:158-160.

Scholl, W. and E. Schwemmer. 1982. Verwendung und Untersuchung von Baumrinden und Rinden produkten. Deutscher Gartenbau 36(8):330-334.

Senesac, A.F. 2002a. Cornell pest management guidelines for commercial production of herbaceous perennials. Cornell Univ. Media and Technol. Serv., New York.

Senesac, A. F. 2002b. Weed management in herbaceous perennials. Proc. Pennsylvania Landscape Nursery Conf. p. 17-22.

Senesac, A.F. 2004. Total plant management of herbaceous perennials. Maryland Coop. Ext. Bul. 359

Skroch, W.A., M.A. Powell, T.E. Bilderback, and P.H. Henry. 1992. Mulches: Durability, aesthetic value, weed control, and temperature. J. Environ. Hort. 10(1):43-45.

Simpson, C.V., C.H. Gilliam, J.E. Altland, G.R. Wehtje, and J.L. Sibley. 2002. Postemergence oxalis control in container-grown crops. Proc. Southern Nursery Assn. Res. Conf. 47:376-379.

VanGessel, M.J. 2001. Glyphosate-resistant horseweed from Delaware. Weed Sci. 49(6):703-705.

Vencill,W.K. 2002. Herbicide handbook, 8thed. Weed Science Soc. Amer., Lawrence, Kans.

Walker, K.L. and David J. Williams. 1989. Annual grass interference in container-grown bush cinquefoil (Potentilla fruiticosa). Weed Sci. 37(1):73-75.

Weed Technology. 1996. Appendix. 10:10021004.

Wehtje, G.R., C.H. Gilliam, and B.F. Hajek. 1993. Adsorption, desorption, and leaching of oxadiazon in container media and soil. HortScience 28:126-128.

Wilen, C.A., U.K. Schuch, and C.L. Elmore. 1999. Mulches and subirrigation control weeds in container production. J. Environ. Hort. 17(4):174-180.

Winton, K. and J.B. Weber. 1996. A review of field lysimeter studies to describe the environmental fate of pesticides. Weed Technol. 10(1):202-209. 